\title{
Racotumomab in Non-Small Cell Lung Cancer as Maintenance and Second-Line Treatment
}

\author{
Haslen H. Cáceres-Lavernia MD MS, Elia Nenínger-Vinageras MD PhD, Leslie M. Varona-Rodríguez MD, \\ Yoli A. Olivares-Romero MD, Irlis Sánchez-Rojas MD MS, Zaima Mazorra-Herrera PhD, Denenke Basanta-Bergolla MD, \\ Dayanis Duvergel-Calderín MD MS, Boris L. Torres-Cuevas MD MS, Concepción del Castillo-Carrillo MD
}

\begin{abstract}
INTRODUCTION Racotumomab is a therapeutic vaccine based on a monoclonal anti-idiotypic antibody developed by the Molecular Immunology Center in Havana, Cuba, that is registered in Cuba and Argentina for treatment of non-small cell lung cancer. It induces a specific humoral and cellular immune response against the N-glycolyl GM3 (NeuGcGM3) ganglioside present in tumor cells, thereby provoking the death of these cells.
\end{abstract}

OBJECTIVE Evaluate racotumomab vaccine use as switch maintenance and second-line therapy for patients with inoperable non-small cell lung cancer in routine clinical practice, outside the framework of clinical studies, and assess the overall survival, stage-specific survival and safety in these patients.

METHODS A descriptive, retrospective study was carried out in patients diagnosed with non-small cell lung cancer not suitable for surgical treatment, who received racotumomab as a part of switch maintenance or second-line treatments. Overall

\section{INTRODUCTION}

Lung cancer is one of the most frequent neoplasms in the world. In 2020 , it accounted for $11.7 \%$ of new cancer cases and $18.0 \%$ of reported cancer deaths.[1,2] In Cuba, the highest cancer incidence rates in men correspond to skin, prostate and lung cancer; and in women to skin, breast and lung cancer. In both sexes, lung cancer ranks third in incidence and first in mortality (5626 deaths in 2019; of which 3406 were men and 2220 were women).[3]

Smoking is the most common etiological factor, present in about $95 \%$ of male and $80 \%$ of female patients affected worldwide. Factors associated with lung cancer occurrence in nonsmokers include environmental pollution, exposure to radon and other occupational substances, diet, lifestyle and genetic predisposition.[4,5]

Malignant epithelial lung tumors are classified into two major groups: small cell or microcytic lung carcinomas $(15 \%-25 \%)$ and non-small cell or non-microcytic lung carcinomas $(75 \%-85 \%)$. The second group includes three main types: adenocarcinoma (40\%), squamous cell carcinoma (25\%) and large-cell carcinoma

IMPORTANCE This is the first report on use of racotumomab in treatment of non-small cell lung carcinoma as part of routine clinical practice outside the context of a clinical trial. survival was defined from diagnosis and from the first immunization, until death.

RESULTS We included 71 patients treated with racotumomab, $57.7 \%(41 / 71)$ of whom were in stages IIIB and IV of non-small cell lung cancer. Of the patients, $84.5 \%(60 / 71)$ had no adverse events, and $15.5 \%(11 / 71)$ had mild adverse reactions. The median overall survival was 24.5 months, calculated from the first immunization, 17.2 months for those who received racotumomab as switch maintenance and 6.8 months for patients who had progressed after the first line of treatment.

CONCLUSIONS Racotumomab in routine clinical practice prolonged overall survival in patients with non-small cell lung cancer treated in switch maintenance, and in stage IV patients who received the treatment as second-line therapy. The vaccine was well tolerated.

KEY WORDS Racotumomab; carcinoma, non-small cell lung; lung neoplasms; Cuba

$(10 \%) .[4,5]$ Adenocarcinoma usually occurs in young, female nonsmokers with genetic alterations.

Worldwide, the median age of lung cancer diagnosis is 70 years, with a high incidence of cases from 65 to 75 years of age. Of these, $50 \%-70 \%$ are diagnosed with locally advanced or metastatic disease, and 5-year survival is only $17 \%-18 \%$.[4-6] For nonsmall cell lung carcinoma, the International Association for the Study of Lung Cancer (IASLC) reports 5-year survival for stages IIIA, IIIB, IIIC, and IV as $36 \%, 26 \%, 13 \%$, and $6 \%$, respectively.[7]

For patients in early stages of the disease who are unable to undergo surgical treatment or who refuse surgery, and for patients with locally advanced and metastatic disease, concurrent or sequential chemotherapy with radiotherapy is the therapeutic option of choice.[4,6] Traditionally, first-line treatment is chemotherapy with platinum derivatives (cisplatin, carboplatin) combined with other agents (such as pemetrexed, gemcitabine, vinorelbine, paclitaxel, docetaxel, bevacizumab).[5,6] However, their efficacy is limited, with little increase in survival, and high toxicity can cause discontinuation of treatment or precludes their application.

In recent years, important changes have been introduced in the treatment of non-small cell lung carcinoma, including therapies directed at targets on tumor cells' epidermal growth factor receptor (EGFR) or anaplastic lymphoma kinase (ALK)[6] and therapies that activate the immune system against the tumor. Among these are therapies that block the immune checkpoint represented by the programmed 
death receptor and its ligand PD-1/PD-L1 (atezolizumab, nivolum$a b$, pembrolizumab) and immune checkpoint inhibitors of cytotoxic T-lymphocyte-associated antigen 4 or CTLA-4 (ipilimumab).[8-10]

Understanding cell signaling mechanisms and their role in tumor formation, the use of monoclonal antibodies and recombinant proteins and the development of immunotherapy have opened new therapeutic avenues, among them immune response activation against tumor cells by means of vaccines based on tumor antigens. The Molecular Immunology Center (CIM) in Havana, Cuba, developed the racotumomab vaccine based on a murine monoclonal anti-idiotype antibody belonging to the IgG1 subclass.[11-14] Racotumomab stimulates an immune response against the tumor antigen N-glycolyl GM3 (NeuGcGM3). This ganglioside is virtually undetectable in normal cells; however, it is present in the cells of certain tumors (melanoma, breast, non-small cell carcinoma, Wilms tumor and neuroblastoma monocytes).[15,16] Its overexpression has been associated with altered cell growth, immune tolerance and tumor metastasis and angiogenesis, making it a target for cancer therapy.[14,15]

The response induced by antibodies generated after immunization with racotumomab is understood, as is its mechanism of action.[17] Most patients generate antibodies capable of binding to NeuGcGM3-expressing tumor cells, destroying them by a nonapoptotic mechanism, independent of complement activation.[17] Racotumomab's use in 20 patients with advanced-stage nonsmall cell lung cancer who had received 4 to 6 cycles of cisplatin/ vinblastine induced an $\lg \mathrm{M}$ and $\lg G$ antibody response against NeuGcGM3.[18]

A meta-analysis including 26 studies and 7839 patients with stage III and IV non-small cell lung cancer found that racotumomab and pemetrexed maintenance therapies were the most effective in terms of overall survival and disease-free survival.[19] A phase $2 / 3$ trial involving 87 patients with advanced non-small cell lung cancer also showed an increase in overall survival and progression-free survival, and found local reactions at the injection site, bone pain, cough and asthenia to be the main adverse reactions, leading to the conclusion that the product is effective and safe.[20] It exhibits very low toxicity and is well tolerated, so patients sustain longterm treatment without complications, gaining control of disease symptoms, with increased survival and a substantial improvement in quality of life.[21] Racotumomab (trade name: Vaxira) is registered in Cuba[22] and Argentina[13] for treatment of patients with non-small cell lung carcinoma.

The objective of this study was to report on the use of racotumomab in early and advanced stages of the disease, as part of routine clinical practice outside the context of a clinical investigation for patients who could not receive surgical treatment. Its use as switch maintenance or second-line therapy is described.

\section{METHODS}

We conducted a descriptive, retrospective, non-probability sampling study to evaluate survival in patients with non-small cell lung carcinoma who could not be treated by surgery, and who received racotumomab as switch maintenance or second-line therapy.

Of the 86 patients seen in the Oncology Service of the Hermanos Ameijeiras Clinical-Surgical Hospital in Havana, Cuba, from
January 2010 through December 2014, with cyto/histological confirmation of non-small cell lung carcinoma who did not undergo surgery, and who had received the racotumomab vaccine, 71 patients were selected who had completed first-line treatment with chemotherapy, radiotherapy or both, and whose clinical charts had the information required for this study. Of these, 36 received the vaccine as switch maintenance (new treatment given immediately following first-line treatment, requiring no evidence of disease progression) and 35 as second-line treatment (introduced after evidence of failure of first-line treatment due to disease progression).

Vaccine administration route, dosage and frequency Racotumomab (1 $\mathrm{mg} / \mathrm{mL}$, with alumina as adjuvant) was administered intradermally in 4 subdoses of $0.25 \mathrm{~mL}$, in deltoid regions and anterior surface of the forearms. The first 5 doses were administered at 14-day intervals ( \pm 7 days of tolerance), the following doses at 28-day intervals ( \pm 15 days of tolerance), provided that the patient's general condition permitted subsequent doses.

Statistical analysis Data was obtained by reviewing medical records in hospital archives, the primary registry and the database of the Oncology Service's Functional Thoracic Tumor Unit. We created a database using SPSS version 20 in which age, sex, histologic type, smoking habit, tumor location, comorbidities, clinical stage, treatments received, vaccine immunizations and causes of immunotherapy discontinuation were recorded.

The main variables studied were: overall survival, defined as time elapsed from diagnosis or from first immunization to death or knowledge of the latest update; survival according to progressors and non-progressors at initiation of treatment with the vaccine and by stage (stages I and II were reported together). Survival estimation was made using the Kaplan-Meier method. Severity of adverse effects was assessed according to the US National Cancer Institute's Common Terminology Criteria for Adverse Events version 4.0.[23]

\section{RESULTS}

Median age of patients was 66 years. Of the total, $67.6 \%(48 / 71)$ presented at least one comorbidity and the vast majority were smokers. More than half of patients $(57.7 \%, 41 / 71)$ were in locally advanced or metastatic stages. The main histologic subtype was adenocarcinoma, followed by squamous cell carcinoma. It was not possible to determine the histologic subtype in 13 patients (18.3\%) (Table 1).

Most patients $(73.2 \%, 52 / 71)$ had undergone chemotherapy in addition to radiotherapy; $94.4 \%(67 / 71)$ adhered to the first-line treatment schedule (chemotherapy, radiotherapy, 4-6 cycles); only 4 patients $(5.6 \%)$ received less than 4 cycles, 3 due to hematologic toxicity and 1 due to nephrotoxicity.

Of the total, $98.6 \%(70 / 71)$ of patients adhered to the vaccine induction phase (first 5 doses administered at 14-day intervals); $38.0 \%(27 / 71)$ received over 14 vaccine administrations during more than one year of treatment. The most frequent cause of treatment discontinuation was disease progression (57 patients) and 2 dropped out of vaccination (Table 2). $84.5 \% \quad(60 / 71)$ had no adverse events following immunization, and 15.5\% (11/71) reported some mild events (Table 3 ). 
Table 1: Patient characteristics

\begin{tabular}{|c|c|c|}
\hline Variable & Categories & $\mathbf{N}(\%)$ \\
\hline \multirow{2}{*}{ Sex } & Female & $23(32.4)$ \\
\hline & Male & $48(67.6)$ \\
\hline \multirow{3}{*}{ ECOG } & 0 & $14(19.7)$ \\
\hline & 1 & $48(67.6)$ \\
\hline & 2 & $9(12.7)$ \\
\hline \multirow{3}{*}{$\begin{array}{l}\text { Presence of } \\
\text { comorbidities }\end{array}$} & No & $23(32.4)$ \\
\hline & One & $27(38.0)$ \\
\hline & Multiple & $21(29.6)$ \\
\hline \multirow{3}{*}{ Tobacco use } & Ex-smoker & $9(12.7)$ \\
\hline & Smoker & $57(80.3)$ \\
\hline & Non-smoker & $5(7.0)$ \\
\hline \multirow{7}{*}{ Disease stage } & IA & $3(4.2)$ \\
\hline & IB & $4(5.6)$ \\
\hline & IIA & $4(5.6)$ \\
\hline & IIB & $4(5.6)$ \\
\hline & IIIA & $15(21.1)$ \\
\hline & IIIB & $15(21.1)$ \\
\hline & IVA, IVB & $26(36.6)$ \\
\hline \multirow{4}{*}{ Histological type } & $\begin{array}{l}\text { Non-small cell carcinoma (not other- } \\
\text { wise specified) }\end{array}$ & $13(18.3)$ \\
\hline & Adenocarcinoma & $28(39.4)$ \\
\hline & Squamous cell carcinoma & $22(31.0)$ \\
\hline & Undifferentiated large-cell carcinoma & $8(11.3)$ \\
\hline \multirow{2}{*}{ First-line treatment } & Chemotherapy/radiotherapy & $52(73.2)$ \\
\hline & Chemotherapy & $19(26.8)$ \\
\hline \multirow{4}{*}{$\begin{array}{l}\text { Chemotherapy } \\
\text { regimen }\end{array}$} & Cisplatin or Carboplatin/VP16 & $11(15.5)$ \\
\hline & Cisplatin or Carboplatin/VLB & $50(70.4)$ \\
\hline & Cisplatin or Carboplatin/paclitaxel & $6(8.4)$ \\
\hline & Cisplatin & $4(5.6)$ \\
\hline \multirow{4}{*}{$\begin{array}{l}\text { Response to first-line } \\
\text { treatment }\end{array}$} & Complete tumor remission & $1(1.4)$ \\
\hline & Partial tumor remission & $22(31.0)$ \\
\hline & Stable illness & $32(45.1)$ \\
\hline & Progression & $16(22.5)$ \\
\hline
\end{tabular}

ECOG: functional capacity according to the Eastern Cooperative Oncology Group scale;[24] VLB Vinblastine; VP16: Etoposide

Median overall survival from the time of diagnosis was 24.5 months, (95\% Cl: 19.03-30.10), with a 5-year survival rate of $17.3 \%$. Patients who received racotumomab as switch maintenance achieved median survival from the start of immunization of 17.2 months. In patients who received racotumomab as second-line treatment, median survival was 6.8 months (Table 4 and Figure 1).

For the 41 patients in stages IIIB and IV, median overall survival from first immunization was 11.3 months, 15.8 months for patients who were non-progressors at the start of treatment with the vaccine, and 9.0 months for patients who were progressors at the start of treatment with the vaccine, for a rate of $51.2 \%$ at 2 years and $7.0 \%$ at 5 years. Stage IV patients who were progressors at treatment initiation attained 10.2 months of survival, and patients who were non-progressors at treatment initiation attained 15.1 months of survival (Table 4).

\section{DISCUSSION}

Lung carcinoma occurs more frequently in men and individuals between 65 and 75 years of age with an average age of 70 years. $[4,6]$ In our study, most patients were over 60 years of age.
Table 2: Treatment with racotumomab vaccine: induction and immunizations

\begin{tabular}{|l|c|}
\hline Compliance with vaccine induction phase & $\mathbf{N}(\%)$ \\
\hline Yes & $70(98.6)$ \\
\hline No & $1(1.4)$ \\
\hline Number of immunizations & $\mathbf{N}(\%)$ \\
\hline $1-5$ & $15(21.1)$ \\
\hline $6-9$ & $18(25.4)$ \\
\hline $10-14$ & $11(15.5)$ \\
\hline$>14$ & $27(38.0)$
\end{tabular}

Table 3: Frequency and characterization of adverse events following immunization with racotumomab

\begin{tabular}{|c|c|}
\hline Adverse event following immunization & $\begin{array}{c}\text { Frequency* } \\
\text { N (\%) }\end{array}$ \\
\hline Yes & $11(15.5)$ \\
\hline No & $60(84.5)$ \\
\hline \multicolumn{2}{|l|}{ Type of adverse event (degree of toxicity) } \\
\hline \multicolumn{2}{|l|}{ Systemic: } \\
\hline Low-grade fever (I) & $2(2.8)$ \\
\hline Arthralgia (I) & $1(1.4)$ \\
\hline Myalgia (I) & $1(1.4)$ \\
\hline \multicolumn{2}{|l|}{ Local: } \\
\hline Redness at the injection site (I) & $5(7.0)$ \\
\hline Pain at the injection site $(I)$ & $2(2.8)$ \\
\hline
\end{tabular}

Degree of toxicity: according to the scale of the National Cancer Institute, USA.[23] ${ }^{*}$ Frequency: adverse event frequency of occurrence (number of patients experiencing the event)

Table 4: Survival in months since start of racotumomab immunization, by cancer stage and progressor/non-progressor status

\begin{tabular}{|c|c|c|}
\hline & Progressors & Non-progressors \\
\hline $\begin{array}{l}\text { Cancer } \\
\text { stage }\end{array}$ & $\begin{array}{l}\text { Median survival in months } \\
\text { (Cl 95\%) }\end{array}$ & $\begin{array}{l}\text { Median survival in months } \\
\text { (Cl 95\%) }\end{array}$ \\
\hline I and II & $4.0(0.00-8.07)$ & $39.9(10.61-69.18)$ \\
\hline IIIA & $4.7(0.00-11.12)$ & $12.9(0.00-38.93)$ \\
\hline IIIB & $5.2(2.94-7.45)$ & $16.5(14.39-18.67)$ \\
\hline IV & $10.2(4.22-16.17)$ & $15.1(5.81-24.51)$ \\
\hline
\end{tabular}

Non-progressors: 36 patients who at the time of first immunization were progressors and who received racotumomab as switch maintenance therapy.

Progressors: 35 patients who at the time of first immunization were progressors and who received racotumomab as second-line treatment.

Patients at disease diagnosis had predominantly functional capacity according to the scale used by the Eastern Cooperative Oncology Group (ECOG),[24] with at least one comorbidity. Most patients (93\%) were active or former smokers; these data are similar to those reported elsewhere in the literature: $85 \%-90 \%$ of patients with non-small cell carcinoma are or have been smokers. Tobacco use is associated with oncologic, cardiovascular, pulmonary, renal and infectious diseases.[4,25]

It has been reported that $50 \%-70 \%$ of patients are diagnosed at locally advanced and metastatic stages, for which there are no curative treatments.[5,6] Locally advanced and metastatic stages also predominated in this study. In $18.3 \%$ (13) of patients, the histologic subtype could not be defined and was classified as nonsmall cell lung carcinoma (not otherwise specified). In patients classified histologically, adenocarcinoma predominated (39.4\%). 
Figure 1: Overall survival since beginning immunization

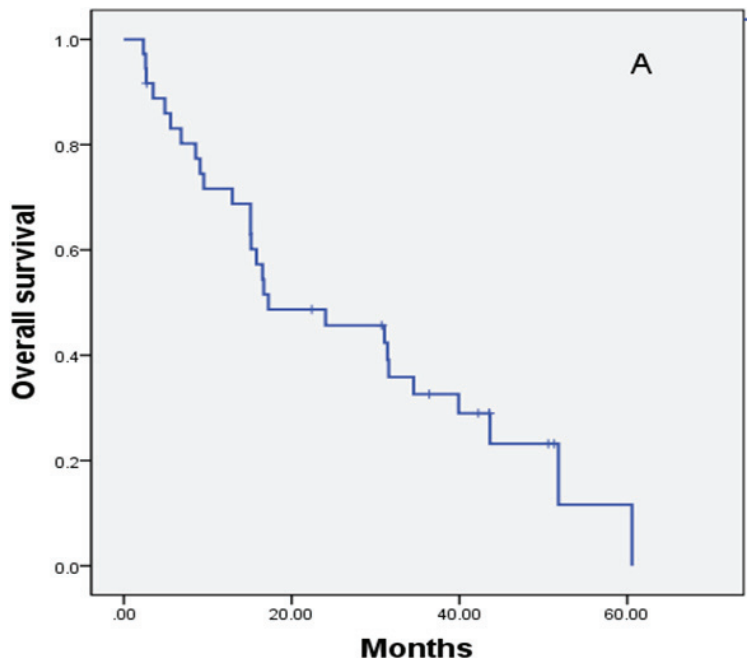

A: Patients treated with racotumomab in switch maintenance (non progressors: 36 patients with stable disease, with partial or complete response after first-line treatment). Median overall survival: 17.2 months $(95 \% \mathrm{Cl}, 0.26-34.20)$.

Overall survival: Proportion of surviving patients (1.0: all alive, 0.0: all dead).

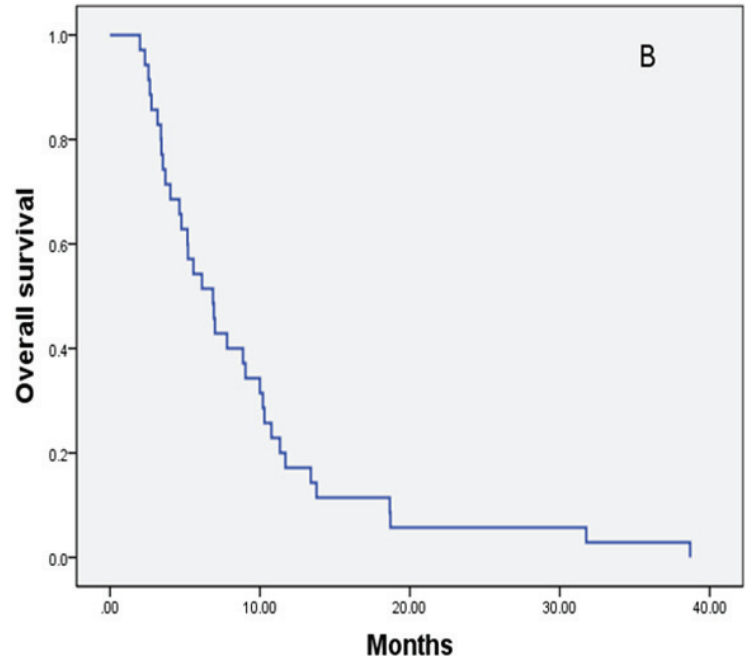

B: Patients treated with racotumomab in second-line treatment (progressors: 35 patients with progressing disease). Median overall survival: 6.86 months $(95 \% \mathrm{Cl}, 4.78-8.95)$.

Overall survival: Proportion of surviving patients (1.0: all alive, 0.0: all dead).

Adenocarcinoma is the most frequent subtype in non-small cell lung carcinomas.[26,27] In this subgroup, which has experienced an increase in incidence rates worldwide, there have also been important advances in diagnosis and treatment, thanks to the identification of mutations in EGFR genes and ALK gene fusion, in which treatment with tyrosine kinase inhibitors has led to longer survival than that achieved with chemotherapy plus radiotherapy. $[6,28]$

The most effective chemotherapy combines a platinum derivative with another antitumoral (cisplatin or carboplatin plus paclitaxel, gemcitabine, docetaxel, vinorelbine, irinotecan or pemetrexed). Most patients included in this study received cisplatin with vinblastine as first-line therapy, as was the case in the Alfonso study (176 randomized patients with stage IIIB/IV disease, a study coordinated by the Cuban National Oncology and Radiobiology Institite).[20] Almost all patients completed the prescribed cycles of chemotherapy. Prolongation of treatment up to six cycles may lead to increased toxicity with poor or no overall survival benefit. $[6,29,30]$ For first- and second-line treatment in advanced lung carcinoma, six cycles of chemotherapy are recommended for patients who are non-progressors after the fourth cycle and who cannot receive switch maintenance or immunotherapy.[6,29,30]

At the end of first-line treatment (chemotherapy, radiotherapy, or both), stable disease and partial remission was predominant among patients. This is a tumor that responds poorly to chemotherapy and for which the treatment of choice is surgery (not applicable to these patients for various reasons).[29,31]

Clinical studies[31,32-34] have shown that the racotumomab vaccine increases survival in patients with recurrent or advanced stage (IIIB/IV) non-small cell lung cancer, compared to patients treated with best-practice supportive care. The vast majority in our research $(70 / 71 ; 98.6 \%)$ completed the induction phase (the first four cycles of the vaccine), the completion of which results in a better immune response. Most $(53.5 \%, 38 / 71)$ received 10 or more immunizations, and continued vaccination for more than one year until clinical progression of the disease, which was the predominant cause for discontinuation of treatment.

Adverse events were minimal, characterized mainly by mild local reactions (none leading to discontinuation of treatment or affecting patients' health). In earlier clinical trials, racotumomab proved to be a very well-tolerated vaccine, with a low toxicity profile. $[21,29,34,35]$ Viada[36] evaluated adverse events in six clinical trials designed to assess the vaccine's safety profile and efficacy at various tumor sites. No serious adverse events were reported; the most frequent adverse events occurred at the injection site, and systemic reactions consisted of fever, myalgias, arthralgias, pruritus, headache and fatigue, and generally subsided in less than 48 hours. These results are consistent with ours and with those reported by Pérez,[35] who assessed safety in 86 patients with non-small cell carcinoma.

\section{Survival}

Overall survival The most informative indicators of cancer severity and treatment efficacy is overall survival rate and disease-free survival rate. The overall survival rate at 5 years in patients with non-small cell carcinoma in the United States is 18\%,[4] 9\%-13\% with a median survival of $9-12$ months, and $30 \%-40 \%$ at 2 years and $10 \%$ at 5 years in the European Cancer Registry in Spain.[37]

Various studies[29,32,34] have shown that the racotumomab vaccine increases survival in patients with recurrent or advanced stage (IIIB/IV) non-small cell lung carcinoma compared with patients treated with best-practices supportive care. The first study with racotumomab in patients with stage IIIB and stage IV non-small cell carcinoma reported median overall survival of 16.4 months from time of diagnosis and a median survival of 9.93 months from time of vaccination, for a 1-year survival rate of $34 \%$.[29]

One of the most important clinical studies with racotumomab in patients with stage IIIB and stage IV non-small cell carcinoma evaluated the effectiveness of treatment in 176 randomized 
patients -87 treated with the vaccine and 89 with placebo. [20] Median overall survival was 8.2 months and 6.8 months, respectively. Median progression-free survival in vaccinated patients was 5.33 months versus 3.9 months for the placebo group. This study demonstrated for the first time the superiority of racotumomab over placebo in a randomized, controlled clinical trial.

The overall survival rate in the present study was $17.3 \%$ at 5 years. In stages IIIB and IV, a survival rate of $51.2 \%$ was observed at 2 years, which falls to $7 \%$ at 5 years, with a median survival of 11.3 months.

Overall survival in our study was 24.5 months from time of diagnosis. Median survival was 17.2 months from first immunization in patients who received the vaccine as switch maintenance after first-line treatment, with a survival rate at 1 year of $69 \%$. In the subgroup that received the vaccine as secondline therapy, median survival was 6.86 months and the survival rate at 1 year was $17.1 \%$. In the subgroup of patients who were progressors at the start of vaccine therapy, the data coincides with that reported by Alfonso; $[20,29]$ in patients who received the vaccine as switch maintenance, overall survival was higher. This could be explained by the fact that this study includes all cases seen in routine medical practice involving patients in early disease stages. For the 41 patients in stages IIIB and IV, median overall survival was 11.3 months from first immunization (15.8 months for patients in switch maintenance and 9.0 months for patients undergoing second-line treatment). Survival was higher in the present study than in the clinical trials conducted in Cuba.[20,29]

Survival in non-small cell lung carcinoma depends on early detection, early initiation of treatment and, especially, early surgical treatment. Survival in stage IA or IB patients undergoing surgery is $60 \%-80 \%$ at 5 years, while in patients receiving no treatment, survival does not exceed 6\%.[7] Overall survival in advanced stages treated with chemotherapy (platinum plus a third-generation drug) and radiotherapy is only 10-12 months and the 1 -year survival rate is $30 \%-40 \%$.

Hardstock reported an overall survival of 11.1 months for patients without noteworthy genetic mutations treated with first-line chemotherapy, and 18.8 months for patients with mutations who were treated with a tyrosine kinase inhibitor.[38] In a European study, overall survival after first-line chemotherapy was 10.3 months.[39] The FLEX study in patients with stage III and IV non-small cell lung carcinoma reported 11.3 months overall survival for patients treated with standard chemotherapy plus cetuximab, and 10.1 months for those who received only standard chemotherapy.[40]

Our survival results in stages I and II differ from those published by Arnold.[41] In our study, no patient received surgical treatment (even in early stages) because surgery was contraindicated. Our results are better in stages IIIB and IV. The lower survival in stage IIIA, as compared to IIIB, could be due to the fact that most of these patients were already progressors at the start of immunization with the vaccine.

Switch maintenance The results in our investigation in the 36 patients who received racotumomab as switch maintenance are similar to those reported with the vaccine in previous studies and with other maintenance therapies.[19,20,31,32]
Many drugs approved as maintenance or switch maintenance therapies that have demonstrated longer overall survival and better symptomatic control also entail substantial toxicity: docetaxel, bevacizumab, pemetrexed, gemcitabine and erlotinib. Of these, pemetrexed is the best tolerated.[42-44] Maintenance with pemetrexed has demonstrated efficacy after induction therapy with a platinum doublet and after cisplatin-pemetrexed combination,[44] with similar increases in overall survival and progression-free survival in both studies (median of 13 and 4 months, respectively). In a phase 3 clinical trial of 663 patients diagnosed with non-small cell lung carcinoma, an overall survival of 13.4 months was attained in the group treated with pemetrexed as switch maintenance therapy, compared to 10.6 months in the placebo group.[45]

Immunotherapy today is one of the most important treatment avenues for lung cancer. The KEYNOTE-021 study[9] included non-progressor patients with various levels of PD-L1 expression. Longer survival (34.5 months) was attained in patients who received the humanized monoclonal antibody pembrolizumab in combination with chemotherapy as first-line treatment than in those who received chemotherapy alone. This result is superior to ours (24.5 months) in terms of overall survival from diagnosis, possibly because our study included patients at all stages as well as patients in progression at the start of vaccination, and because the population under study was not stratified by tumor molecular studies.

In the period under study, no stratification studies were performed using molecular markers, which currently allow a priori discrimination of potential responders from non-responders. Some patients treated with racotumomab could present genetic alterations; mutation of the epidermal growth factor receptor, ALK translocations or ROS-1-positive status, for example; it is now known that the vaccine is not effective in these patients because these signaling pathways are aberrant.

Second-line treatment Docetaxel has been standard secondline treatment for non-small cell non-squamous lung carcinoma progressing after treatment with a platin doublet, with median overall survival of 7.5 months, a median duration of response of approximately 26 weeks, and an overall one-year survival rate of approximately 37\%.[46] A multicenter phase 3 clinical trial comparing atezolizumab and docetaxel in second-line treatment in patients with non-small cell carcinoma reported improved overall survival in the group treated with atezolizumab. In patients with non-small cell non-squamous carcinoma, median overall survival was 15.6 and 11.2 months for atezolizumab and docetaxel, respectively (hazard ratio of 0.73 ; $95 \% \mathrm{Cl}$ : $0.60-0.89$ ) and in patients with non-small cell squamous carcinoma, overall survival was 8.9 and 7.7 months for atezolizumab and docetaxel, respectively (hazard ratio: $0.73 ; 95 \% \mathrm{Cl}$ : 0.54-0.98).[47] $\mathrm{A}$ multicenter study evaluating survival in patients with non-small cell carcinoma treated with racotumomab as second-line therapy reported an overall survival of 8.9 months.[48]

In the present study, overall survival from the start of immunization in 35 patients treated with racotumomab as second-line was 6.8 months, slightly lower than that reported by Rittmeyer and by Santiesteban, $[47,48]$ who also did not perform molecular studies to stratify patient treatment according to mutations or immunohistochemistry. Our patients who received treatment in 
stage IV attained 10.2 months of survival, exceeding that reported by Rittmeyer[47] and Santiesteban,[48] and also superior to our results for stage IIIB, although the latter sample included only 4 patients.

Our results coincide with those of Alfonso in the first study performed with racotumomab in lung cancer[29] (which obtained better survival for stage IIIB and IV patients who responded to first-line chemotherapy) and were superior to those obtained in a noninferiority clinical trial that evaluated the efficacy of racotumomab, nimotuzumab and docetaxel as second-line treatment,[49] in which median survival times of 4.8, 4.6 and 5.8 months, respectively, were obtained.

Limitations of this study Although the information provided by a retrospective study does not have the same confirmatory value as a prospective study, the rigorous selection of clinical histories and information quality control give this study, the only one of its kind in Cuba, great value as support for use of racotumomab in clinical practice. Histologic subtype could not be defined in some patients, which prevented a more refined histologic stratification.
Nor were methods available to determine genetic markers to which prognostic value is currently attributed (ALK translocations, ROS1 positive, EFG receptor mutation and other genetic disorders). Patients with these mutations currently benefit from tyrosine kinase inhibitors, permitting higher survival rates.

\section{CONCLUSIONS}

This is the first study of racotumomab use outside a clinical investigation and as part of routine clinical practice. Racotumomab is an option for switch maintenance for patients with non-small cell lung carcinoma. It is well-tolerated; adverse events do not increase with the number of immunizations, and it is safe for prolonged use. Our survival results in patients treated with second-line racotumomab who were progressors at treatment initiation were slightly lower than those reported in some clinical trials, and similar to or greater than those reported in other trials. It is important to conduct clinical trials in patient populations selected through molecular marker studies, in which racotumomab is combined with other antineoplastic agents recently introduced for specified use depending on the presence of molecular markers. - 1 -

\section{REFERENCES}

1. International Agency for Research on Cancer (IARC); World Health Organization (WHO). Lung. Number of deaths in 2020 both sexes, all ages [Internet]. Lyon: International Agency for Research on Cancer (IARC); 2020 Dec [cited 2021 Jan 12]. 2 p. Available at: https://gco.iarc .fr/today/data/factsheets/cancers/15-Lung-fact -sheet.pdf

2. Globocan. Lung Cancer Fact Sheet [Internet]. [cited 2021 Jan 12]. Available at: https//gco.iarc .fr/today/fact-Sheets-cancers/

3. National Health Statistics and Medical Records Division (CU). Anuario Estadístico de Salud 2019 [Internet]. Havana: Ministry of Public Health (CU); 2020 [cited 2021 Jan 12]. Available at: https://files.sld.cu/bvscuba/files/2020/05/ Anuario-Electr\%c3\%b3nico-Espa\%c3\%b1ol -2019-ed-2020.pdf. Spanish.

4. National Comprehensive Cancer Network [Internet]. Pennsylvania: National Comprehensive Cancer Network (NCCN); c2021. Guidelines and. Treatment by Cancer Type. NCCN Clinical Practice Guidelines in Oncology (NCCN Guideline®). Survivorship v.2; [updated 2019 Dec 23; cited 2020 Feb 1]. Available at: http://www.nccn .org/professionals/physician_gls/f_guidelines .asp

5. National Cancer Institute [Internet]. Maryland: National Cancer Institute, National Institutes of Health (US); c2021. Cancer types. Lung cancer. Health professional. Non-Small Cell Lung Cancer Treatment $(P D Q \circledast)$. Maryland: National Cancer Institute; 2021 [updated 2021; cited 2021 Jan 7]. Available at: wwwcancergov/cancertopics/pdq/ treatment/non-small-celllung/healthprofessional/ page2

6. Wu YL, Planchard D, Lu S, Sun H, Yamamoto $\mathrm{N}$, Kim DW, et al. Pan-Asian Clinical Practice Guidelines for the management of patients with metastatic non-small-cell lung cancer: a CSCOESMO initiative endorsed by JSMO, KSMO, MOS, SSO and TOS. Ann Oncol. 2019 Feb 1;30(2):171-210. DOI:10.1093/annonc/mdy554

7. Chansky K, Detterbeck FC, Nicholson AG, Rusch VW, Vallières E, Groome P, et al. The IASLC Lung Cancer Staging Project: external validation of the revision of the TNM stage groupings in the eighth edition of the TNM classification of lung cancer. J Thoracic Oncol [Internet]. 2017 Jul [cited 2021 Jan 15];12(7):1109-21. Available at: http://dx.doi. org/10.1016/j.jtho.2017.04.011

8. Goldberg SB. PD-1 and PD-L1 inhibitors: activity as single agents and potential biomarkers in nonsmall cell lung cancer. Am J Hematol Oncol. 2015 Sep 13;11(9):10-3.

9. Awad MM, Gadgeel SM, Borghaei H, Patnaik A, Chih-Hsin Yang J, Powell SF, et al. Long-term overall survival from KEYNOTE-021 Cohort G: Pemetrexed and Carboplatin with or without Pembrolizumab as first-line therapy for advanced nonsquamous NSCLC. J Thorac Oncol [Internet]. 2021 Jan [cited 2021 Jan 15];16(1):162-8. Epub 2020 Oct 15. Available at: https://doi.org/ 10.1016/j.jtho.2020.09.015

10. Brahmer JR, Rodriguez-Abreu D, Robinson AG, Hui R, Csőszi T, Fülöp A, et Al. Healthrelated quality of life for pembrolizumab versus chemotherapy in advanced NSCLC with PD-L1 TPS $\geq 50 \%$ : data from KEYNOTE-024. J Thorac Oncol. 2017 Jan;12(1 Suppl 1):S8-S9.

11. Neninger E, Díaz RM, de la Torre A, Rives R, Díaz A, Saurez G, et al. Active immunotherapy with $1 \mathrm{E} 10$ anti-idiotype vaccine in patients with small cell lung cancer: report of a phase I trial. Cancer Biol Ther. 2007 Feb;6(2):145-50.

12. Vázquez AM, Hernández AM, Macías A, Montero E, Gómez DE, Alonso DF, et al. Racomumomab: an anti-idiotype vaccine related to $\mathrm{N}$-glycolyl-containing gangliosides- preclinical and clinical data. Front Oncol. 2012 Oct 23;2:150:1-6.

13. Disposición 1446 - 13 - ANMAT - Administración Nacional de medicamentos, Alimentos y Tecnología Médica (ANMAT) [Internet]. Buenos Aires: Ministry of Health (AR); 2013 Mar 5 [cited 2021 Jan 11]. 32 p. Available at: www.unq.edu.ar/advf/ documentos/543e96e1e423a.pdf. Spanish.

14. Evaluación de tecnologías sanitarias. Recomendaciones para la utilización de racotumumab. Racotumomab en cáncer de pulmón guía de revisión rápida [Internet]. Buenos Aires: Ministry of Health (AR); 2013 [cited 2021 Jan 11]. Available at: http://www.msal.gob.ar/images/stories/ bes/graficos/0000000847cnt-001-Racotumom ab2013.pdf. Spanish.

15. Samraj AN, Pearce OMT, Läubli $H$, Crittenden AN, Bergfeld AK, Banda K, et al. A red meat-derived glycan promotes inflammation and cancer progression. Proc Natl Acad Sci
USA [Internet]. 2015 Jan 13 [cited 2021 Jan 11];112(2):542-7. Available at: www.pnas.org/ cgi/doi/10.1073/pnas.1417508112

16. Segatori VI, Cuello HA, Gulino CA, Albertó M, Venier C, Guthmann MD, et al. Antibody-dependent cell-mediated cytotoxicity induced by active immunotherapy based on racotumomab in nonsmall cell lung cancer patients. Cancer Immunol Immunother. 2018 Aug;67(8):1285-96

17. Hernández AM, Rodríguez N, González JE, Reyes E, Rondón T, Griñán T, et al. Anti-NeuGcGM3 antibodies, actively elicited by idiotypic vaccination in nonsmall cell lung cancer patients induce tumor cell death by an oncosis-like mechanism. J Immunol. 2011 Mar 15;186(6):3735-44. Epub 2011 Feb 7.

18. Hernández $A M$, Toledo $D$, Martínez $D$, Griñán $T$, Brito $\mathrm{V}$, Macias A, et al. Characterization of the antibody response against neugcgm3 ganglioside elicited in non-small cell lung cancer patients immunized with an anti-idiotype antibody. J Immunol. 2008 Nov 1;181(9):6625-34.

19. Wang $Q$, Huang $H$, Zeng $X$, Ma $Y$, Zhao $X$ Huang M. Single-agent maintenance therapy for advanced non-small cell lung cancer (NSCLC) a systematic review and Bayesian network meta-analysis of 26 randomized controlled trials. Peer J. 2016 Oct 20;4:e2550. DOI: 10.7717/ peerj. 2550

20. Alfonso S, Valdés-Zayas A, Santiesteban ER, Flores YI, Areces F, Hernández $\mathrm{M}$, et al. A randomized, multicenter, placebo-controlled clinical trial of Racotumomab-Alum vaccine as Switch maintenance therapy in advanced non-small cell lung cancer patients. Clin Cancer Res. $2014 \mathrm{Ju}$ 15;20(14):3660-71.DOI:10.1158/1078-0432.CCR $-13-1674$

21. Gajdosik Z. Racotumomab-a novel anti-idiotype monoclonal antibody vaccine for the treatment of cancer. Drugs Today (Barc). 2014 Apr;50(4):3017. DOI: $10.1358 /$ dot.2014.50.4.2116670

22. Center for State Control of Medicines, Equipment and Medical Devices (CU) [Internet]. Havana: Center for State Control of Medicines, Equipment and Medical Devices (CU); c2021. Registro. VAXIRA® (Racotumomab). Reg. No.: B-013001-L03C; [cited 2021 Mar 7]. Available at: https://www.cecmed.cu/registro/rcp/vaxirar-raco tumomab. Spanish. 
23. National Cancer Institute, Divison of Cancer Treatment and Diagnosis - DCTD [Internet] Maryland: National Institutes of Health (US); c2021. Cancer Therapy Evaluation Program Common Terminology Criteria for Adverse Events (CTCAE) v4.0; [updated 2010 Jun 14; cited 2016 Feb 1]. Available at: https://ctep.cancer .gov/protocoldevelopment/electronic_applica tions/ctc.htm\#ctc_40

24. Oken MM, Creech RH, Tormey DC, Horton J, Davis TE, McFadden ET, et al. Toxicity and response criteria of the Eastern Cooperative Oncology Group. Am J Clin Oncol. 1982 Dec;5(6):649-55.

25. Grose D, Devereux G, Milroy R. Comorbidity in lung cancer: important but neglected. A review of the current literature. Clin Lung Cancer. 2011 Jul [cited 2016 Jan 11];12(4):207-11. DOI: 10.1016/j.cllc.2011.03.020

26. Wu YL, Zhou C, Liam CK, Wu G, Liu X, Zhong $Z$, et al. First-line erlotinib versus gemcitabine/ cisplatin in patients with advanced EGFR mutation-positive non-small-cell lung cancer: analyses from the phase III, randomized, open-label, ENSURE study. Ann Oncol [Internet]. 2015 Sep [cited 2021 Jan 11];26(9):1883-9. DOI: 10.1093/ annonc/mdv270. Available at: https://linkinghub .elsevier.com/retrieve/pii/S0923-7534(19)31 770-3

27. Zaki M, Dominello M, Dyson G, Gadgeel S, Wozniak A, Miller S, et al. Outcomes of erderly patiens who receive combined therapy for LA NSCLC in elderly patients clinical lung cancer. 2017 Jan;18(1):e21-e6. DOI: http://dx.doi.org/ 10.1016/j.cllc.2016.07.005

28. García-Campelo R, Bernabé R, Cobo M, Corral J, Coves J, Dómine M, et al. SEOM clinical guidelines for the treatment of non-small cell lung cancer (NSCLC) 2015. Clin Transl Oncol. 2015 Dec;17(12):1020-9. DOI: 10.1007/s12094-015 $-1455-z$

29. Alfonso S, Díaz RM, de la Torre A, Santiesteban $\mathrm{E}$, Aguirre F, Pérez K, et al. 1e10 anti-idiotype vaccine in non-small cell lung cancer: experience in stage IIIb/IV patients. Cancer Biol Ther. 2007 Dec;6(12):1847-52.

30. Planchard D, Popat S, Kerr K, Novello S, Smit EF, Fraive-Finn C, et al. Metastatic non-smal cell lung cancer: ESMO Clinical Practice Guidelines for diagnosis, treatment and follow-up. Ann Oncol. 2020 Oct 1;29(Suppl 4):iv192-iv237.

31. Babu KG, Prabhash K, Vaid AK, Sirohi B, Diwakar RB, Rao R, et al. Nimotuzumab plus chemotherapy versus chemotherapy alone in advanced non-small-cell lung cancer: a multicenter, ramdomized, open-label Fase II study. Onco Targets Ther [Internet]. 2014 Jun 13 [cited 2021 Jan 11];7:1051-60. Available at: https://www.dove press.com/

32. Gómez RE, Alfonso S, Santiesteban ER Neninger $E$, Ardigo ML, Vázquez AM, et al. Active immunotherapy in patients with progressive disease after first line therapy: Racotumomab experience. J Clin Oncol [Internet]. 2013 May 20 [cited 2016 Jan 11];31(15 Suppl):3086. DOI: 10.1200/jco.2013.31.15_suppl.3086. Available at: https://ascopubs.org/doi/abs/10.1200/ jco.2013.31.15_suppl.3086

33. Sokolovska A, Hem SL, Hogen Esch H. Activation of dendritic cells and induction of cd4(+) T cell differentiation by aluminum-containing adjuvants. Vaccine. 2007 Jun 6;25(23):4575-85

34. Hernández AM, Vázquez AM. Racotumomab-alum vaccine for the treatment of nonsmall-cell lung cancer. Expert Rev Vaccines. 2015 Jan;14(1):9-20. Epub 2014 Nov 25 DOI: $10.1586 / 14760584.2015 .984691$

35. Pérez L, Estévez D, Gastón Y, Macias A, Viada CE. Seguridad del Racotumomab en el tratamiento de pacientes con cáncer de pulmón de células no pequeñas. VacciMonitor [Internet] 2013 Jan-Apr [cited 2016 Jan 11];22(1):10-4. Available at: https://www.medigraphic.com/cgi -bin/new/resumen.cgi?IDARTICULO=40754 Spanish

36. Viada C, Fors M, Neninger E, Alfonso S, Santiesteban E, Mendoza I, et al. Seguridad de la vacuna anti-idiotípica 1E10 en pacientes con tumores de diversas localizaciones. Bionatura [Internet]. 2016 [cited 2021 Jan 11];1(1):14-9. Available at: https://www.revistabionatura.com/ files/2-Seguridad-de-la-vacuna-anti-idiotipica -1E10-en-pacientes-Investigacion.pdf. Spanish.

37. Eurocare-5. European cancer registry-based study on survival and care of cancer patients: Eurocare [Internet]. Rome: Institute of Health (IT); 2017 [cited 2017 Oct 5]. Available at: http:// www.eurocare.it/Eurocare5/ResultsEU5/ta bid/90/Default.aspx

38. Hardtstock F, Myers D, Li T, Cizova D, Maywald $\mathrm{U}$, Wilke $\mathrm{T}$, et al. Real-world treatment and survival of patients with advanced non-small cell lung cancer: a German retrospective data analysis. BMC Cancer [Internet]. 2020 Mar 30 [cited 2021 Jan 11];20(1):260. Available at: https://do .org/10.1186/s12885-020-06738-z

39. Moro-Sibilot D, Smit E, de Castro Carpeño J Lesniewski-Kmak K, Aerts J, Villatoro R, et al. Outcomes and resource use of non-small cell lung cancer (NSCLC) patients treated with first-line platinum-based chemotherapy across Europe: FRAME prospective observational study. Lung Cancer [Internet]. 2015 May [cited 2021 Jan 11];88(2):215-22. Available at: https://linkinghub.elsevier.com/retrieve/pii/ S0169-5002(15)00118-X

40. Pirker R, Pereira JR, von Pawel J, Krzakowsk M, Ramlau R, Park K, et al. EGFR expression as a predictor of survival for first-line chemotherapy plus cetuximab in patients with advanced nonsmall-cell lung cancer: analysis of data from the phase 3 FLEX study. Lancet Oncol. 2012 Jan;13(1):33-42. DOI: 10.1016/S1470-2045 (11)70318-7

41. Arnold BN, Thomas DC, Rosen JE, Salazar MC Blasberg JD, Boffa DJ, et al. Lung cancer in the very young: treatment and survival in the National Cancer Date Base. J Thoracic Oncol [Internet]. 2016 Jul [cited 2021 Jan 11];11(7):1121-31. Available at: http://dx.doi.org/10.1016/j.jtho.2016 .03 .023

42. Perol M, Chouaid C, Pérol D, Barlési F, Gervais $\mathrm{R}$, Westeel V, et al. Randomized, phase III study of gemcitabine or erlotinib maintenance therapy versus observation, with predefined second-line treatment, after cisplatin-gemcitabine induction chemotherapy in advanced non-small-cell lung cancer. J Clin Oncol [Internet]. 2012 Oct 1 [cited 2021 Feb 15];30(28):3516-24. Available at: https://ascopubs.org/doi/10.1200/ JCO.2011.39.9782?url ver=Z39.88-2003\&rf id=ori:rid:crossref.org\&rfr_dat=cr_pub\%20\%20 Opubmed

43. Edelman MJ, Le Chevalier T, Soria JC. Maintenance therapy and advanced non-small-cell lung cancer: a skeptic's view. J Thorac Oncol [Internet]. 2012 Sep [cited 2021 Feb 15];7(9):1331-6. Available at: https://linkinghub.elsevier.com/ retrieve/pii/S1556-0864(15)32932-4

44. Patel JD, Socinski MA, Garon EB, Reynolds $\mathrm{CH}$, Spigel DR, Olsen MR, et al. Point break: a randomized phase III study of pemetrexed plus carboplatin and bevacizumab followed by maintenance pemetrexed and bevacizumab versus paclitaxel plus carboplatin and bevacizumab followed by maintenance bevacizumab in patients with stage IIIB or IV nonsquamous non-smallcell lung cancer. J Clin Oncol [Internet]. 2013 Dec 1 [cited 2021 Jan 11];31(34):4349-57. Available at: https://ascopubs.org/doi/10.1200/
JCO.2012.47.9626?url_ver=Z39.88-2003\&rfr id=ori:rid:crossref.org\&rfr_dat=cr_pub\%20\%20 Opubmed

45. Paz-Ares LG, de Marinis F, Dediu M, Thomas M, Pujol JL, Bidoli P, et al. PARAMOUNT: Final overall survival results of the phase III study of maintenance pemetrexed versus placebo immediately after induction treatment with pemetrexed plus cisplatin for advanced nonsquamous non-small-cell lung cancer. J Clin Oncol. 2013 Aug 13 [cited 2021 Jan 12];31(23):2895-902. Available at: https://ascopubs.org/doi/10.1200/ JCO.2012.47.1102?url_ver=Z39.88-2003\&rfr _id=ori:rid:crossref.org\&rfr_dat=cr_pub\%20\%20 Opubmed

46. Shepherd FA, Dancey J, Ramlau R, Mattson K, Gralla R, O'Rourke M, et al. Prospective randomized trial of docetaxel versus best supportive care in patients with non-small-cell lung cancer previously treated with platinum-based chemotherapy. J Clin Oncol. 2000 May;18(10):2095103.

47. Rittmeyer A, Barlesi F, Waterkamp D, Park K, Ciardiello F, von Pawel J, et al. Atezolizumab versus docetaxel in patients with previously treated non-small-cell lung cancer (OAK): a phase 3 open-label, multicentre randomised controlled trial. Lancet. 2017 Jan 21;389(10066):255-65. DOI: 10.1016/S0140-6736(16)32517-X

48. Santiesteban E, Pérez L, Alfonso S, Neninger E, Acosta S, Flores Y, et al. Safety and efficacy of Racotumomab-Alum vaccine as second-line therapy for advanced non-small cell lung cancer. Int J Clin Med [Internet]. 2014 Jul [cited 2021 Jan 12];5(14):844-50. Available at: http://dx.do .org/10.4236/ijcm.2014.514113

49. Hernández $M$, Neninger $E$, Santiesteban $E$ Camacho K, Hernández N, Amador R, et al. Efficacy of racotumomab or nimotuzumab vs docetaxel as second line therapy for advanced non-small cell lung cancer patients. Ann Oncol. 2018 Oct;29(Suppl 8):viii415. DOI:10.1093/ annonc/mdy288 | viii415

\section{THE AUTHORS}

Haslen Hassiul Cáceres-Lavernia (Corresponding author: haslen.caceres@infomed.sld. cu, hassiul1978@gmail.com), oncologist with a master's degree in infectious disease. Hermanos Ameijeiras Clinical-Surgical Hospital (HHA), Havana, Cuba. https://orcid.org/0000 $-0002-5165-4472$

Elia Nenínger-Vinageras, oncologist with a doctorate in medical sciences, HHA, Havana, Cuba. https://orcid.org/0000-0002-0923-1273

Leslie Magdiel Varona-Rodríguez, physician with dual specialties in family medicine and oncology, HHA, Havana, Cuba. https://orcid .org/0000-0002-3305-5871

Yoli Anais Olivares-Romero, oncologist, Social Security and Assistance Institute, (IPASME). Caracas, Venezuela. https://orcid .org/0000-0002-8359-198X

Irlis Sánchez-Rojas, physician with dual specialties in family medicine and oncology, and a master's degree in atherosclerosis, HHA, Havana, Cuba. https://orcid.org/0000-0002-7082-4422

Zaima Mazorra-Herrera, biochemist with a doctorate in biological sciences, Molecular 
Immunology Center, Havana, Cuba. https:// orcid.org/0000-0003-3812-1767

Denenke Basanta-Bergolla, pathologist, HHA, Havana, Cuba. https://orcid.org/0000-0003-44 52-5493

Dayanis Duvergel-Calderín, physician specializing in family medicine and pulmonary medicine, with a master's degree in pathol- ogy, HHA, Havana, Cuba. https://orcid .org/0000-0002-3637-5264

Boris Luis Torres-Cuevas, physician specializing in interventional radiology, with a master's degree in atherosclerosis, HHA, Havana, Cuba. https://orcid.org/0000-0002-4776-0838

Concepción del Castillo-Carrillo, physician with dual specialties in oncology and radiother- apy, HHA, Havana, Cuba https://orcid.org/0000 $-0002-9084-8712$

Submitted: September 13, 2020

Approved for publication: July 8, 2021

Disclosures: Zaima Mazorra-Herrera is employed at the Molecular Immunology Center that produces and registered racotumomab. 